Artigo

\title{
Influence of Plastic Covering on the Microclimate in Vineyards in the São Francisco River Valley Region
}

\author{
Mário de Miranda Vilas Boas Ramos Leitão ${ }^{1}$, Pedro Vieira de Azevedo ${ }^{2}$, \\ Paulo César da Silva Lima ${ }^{1}$, Gertrudes Macário de Oliveira ${ }^{3}$, Carlos Antonio Costa dos Santos ${ }^{2}$ \\ ${ }^{1}$ Universidade Federal do Vale do São Francisco, Petrolina, PE, Brazil. \\ ${ }^{2}$ Unidade Acadêmica de Ciências Atmosféricas, Universidade Federal de Campina Grande, \\ Campina Grande, PB, Brazil. \\ ${ }^{3}$ Universidade do Estado da Bahia, Juazeiro, BA, Brazil.
}

Received in June 29, 2016 - Accepted in May 8, 2017

\begin{abstract}
Data from field experiments conducted in table grape vineyards variety of Festival in Petrolina-PE in the period from September 19 to October 12, 2010 were used to evaluate the influence of plastic cover on microclimate conditions of vineyards in São Francisco River Valley region. Three treatments were studied: canopies without plastic cover (WC); with plastic cover positioned at $50 \mathrm{~cm}$ (PC50), and at $100 \mathrm{~cm}$ (PC100) above canopy. The results indicate that the plastic cover prevented the passage of about $40 \%$ of the global and net radiation, retained the relative humidity inside the canopy, generated an increase of air temperature and marked reduction in wind speed over the canopy of treatment PC50. However, treatment PC100 had a higher incidence of short wavelength and net radiation under canopy (on the berries) than WC and PC50 treatments, resulting in more favorable weather conditions, providing about $40 \%$ greater productivity in this treatment. Therefore, the vineyard with plastic cover placed at $100 \mathrm{~cm}$ above canopy represents a more suitable alternative to the climatic conditions of the region of the São Francisco River Valley.

Keywords: Table grape, radiation balance, air temperature and relative humidity, wind speed.
\end{abstract}

\section{Efeitos da Cobertura Plástica no Microclima em Parreirais na Região do Vale do Rio São Francisco}

\begin{abstract}
Resumo
Dados de experimento de campo conduzido em parreirais de uva de mesa da variedade Festival em Petrolina-PE, no período de 19 de setembro a 12 de outubro de 2010 foram usados para avaliar a influência da cobertura plástica sobre as condições microclimáticas de parreirais na Região do Vale do Rio São Francisco. Estudaram-se três tratamentos: dosséis sem cobertura plástica (WC); com cobertura plástica posicionada a $50 \mathrm{~cm}$ de altura (PC50); e a $100 \mathrm{~cm}$ de altura (PC100). Os resultados indicaram que a cobertura plástica impediu a passagem de cerca de $40 \%$ da radiação global, reteve a umidade relativa no interior dos dosséis, gerou aumento de temperatura do ar e acentuada redução da velocidade do vento sobre o dossel PC50. No entanto, o tratamento PC100 teve maior incidência de onda curta e saldo de radiação sob dossel (sobre as bagas) do que os tratamentos WC e PC50, resultando em condições climáticas mais favoráveis, proporcionando cerca de $40 \%$ a mais de produtividade neste tratamento. Portanto, o parreiral com a cobertura plástica posicionada a $100 \mathrm{~cm}$ de altura representa uma alternativa mais adequada às condições climáticas da região do Vale do São Francisco.

Palavras-chave: Uva de mesa, balanço de radiação, temperatura e umidade relativa do ar, velocidade do vento.
\end{abstract}

\section{Introduction}

The protected grape growing is a worldwide practice, mainly developed in the European countries of the Mediter- ranean region (FAO, 2002; Rana et al., 2004). In Italy, as in other countries, the plastic cover is used for inducing improvement of the thermos-hygrometric conditions when the

Corresponding author: Carlos Antonio Costa dos Santos, carlos.santos@ufcg.edu.br. 
atmosphere has to be unfavorable to the growth and development of the plants, particularly the adverse weather conditions of wind and rain (Gambino et al., 2008).

In Brazil, the plastic cover of vineyards was first introduced in the Rio Grande do Sul, dominated by cold climate with rainfall and strong winds and hail at the time of grape maturation, conditions that cause cracks and installation diseases (Chavarria and Santos, 2009). Later, the use of plastic cover occurred in Paraná (Genta et al., 2010) and Sao Paulo (Lulu et al., 2005; Pedro Junior, 2006; Colombo et al., 2011). According with information of the Agricultural Cooperative of Juazeiro - BA (ACJ), the use of the plastic cover in the Sao Francisco River Valley region has been taking place since 2000, to protect the vineyards of rain and prevent the occurrence of cracks berries throughout the period of grape maturation and harvesting. Chavarria et al. (2007) state that compared to the unprotected cultivation, the plastic cover provides a differentiation in the microclimate of the vineyards.

Under Brazilian law grape classification, the occurrence of cracks in berries and disease in the grape clusters are classified as a serious defects, which make their marketing expressly prohibited both domestically and externally (Brasil, 2002). In the region of the São Francisco River Valley, the occurrence of occasional rains in some years during the harvest destined for international markets has caused major economic losses to farmers. In view of this, because of the great economic and social importance of table grape growing for the region, the use of plastic cover has become valued in studies on sustainability and competitiveness of viticulture table of the region.

Given the above, the successful commercial production of grapes, whether for consumption in natura or for wine, depends on the correct handling of the variables that make up the microclimate in the vineyards. Particularly, solar radiation, temperature and relative humidity, wind and soil water availability by influencing productivity and grape quality (Santos et al., 2004; Cardoso et al., 2008; Conception and Marin, 2009). Therefore, it is important to research the use of management practices that can provide vineyards most appropriate lighting conditions, as this has a direct influence on microclimate conditions.

The study of the microclimate in the interior of vineyards should be applied both in covered or protected environment production systems, as well as in unprotected vineyards (Gambino et al., 2008; Chorti et al., 2010). Studies have shown that the plastic cover of vineyards causes the following amendments in its microclimate: increases air temperature, reduces photosynthetic active radiation and wind speed, and interfere with the quality of the incoming solar radiation, particularly reducing the ultraviolet, red and far-red bands and consequently on plant physiology, as well as, reduce the incidence of fungal diseases (Chavarria et al., 2009; Conception and Marin, 2009; Mota et al., 2009; Cardoso et al., 2010; Camiran et al., 2012).
Lamas Junior (2008) states that the reduction in solar radiation caused by the plastic cover delays the ripening process of the grapes. However, it is still necessary to deepen these studies to improve the cover system for making their use more efficient and suitable to the climatic conditions of the region. In northeastern Brazil, the use of plastic covering arose from the need to use a protective mechanism against crack berries and installation of fungal diseases, which began to occur in the vineyards of the São Francisco Valley region. However, the phenomenon of splitting of some varieties of grape berries before or during harvesting has occurred in certain locations, associated to the occurrence of heavy rainfall, high temperatures and low incidence of solar radiation (Palma et al., 1999; Vieira et al., 2008). According to Silva et al. (2011), the plastic cover provides a significant increase in air temperature on the canopy and acts as a physical barrier to its movement which effect is greater than its height in relation to the canopy.

Given the above, this study aimed to evaluate the effects of plastic covering on the microclimate of vineyards conditions in the São Francisco Valley region, based on the analysis of the solar radiation, air temperature and relative humidity and wind speed behavior.

\section{Materials and Methods}

The research was conducted with table grape vineyards, variety Festival in the property "Eagle Valley" (9'6'14" S, 40 29'52" W; $360 \mathrm{~m})$, located in the Irrigation Project "Maria Teresa", municipality of Petrolina - PE throughout the phenological phases of maturation and harvesting in the period from September, 19 to October, 12 of 2010. The vineyards were conducted in trellis system and planting on $0.5 \mathrm{~m}$ height ridges and planting spacing of $3.5 \times 2.0 \mathrm{~m}$. It was used as a transparent cover film of lowdensity polyethylene (LDPE) with a thickness of $160 \mathrm{~m}$ and a width of $3 \mathrm{~m}$. Irrigation was made by drip system, with a water depth calculated according to the crop coefficient $(\mathrm{Kc})$ and reference evapotranspiration $\left(\mathrm{ET}_{0}\right)$. The following treatments were studied: uncovered canopy (WC); plastic cover positioned at $50 \mathrm{~cm}$ above the canopy (PC50); and plastic cover positioned at $100 \mathrm{~cm}$ above the canopy (PC100).

For monitoring microclimate variables, micrometeorological stations were installed with the following sensors: net radiometers (Kipp \& Zonen - CNR1), to measure the individual components of radiation balance; psychrometers (Vaisala - HMP45C) to measure air temperature and relative humidity; and anemometers (Young) for measuring wind speed. The sensors were installed: under the canopy at the height of the grapes bunches in all treatments; between canopy and plastic cover in the treatments PC50 and PC100, and above the canopy in the uncovered treatment (WC). In each treatment, the sensors were connected to micrologger automatic data acquisition systems (CR23X and CR1000), programmed to perform readings every $2 \mathrm{~s}$, 
making average hourly and daily, and record the daily extremes of air temperature, humidity and wind speed.

The surface net radiation $(\mathrm{Rn})$, represented by the sum of the radiation fluxes incident and reflected/emitted by the surface vegetation was obtained as (Leitão, 1994):

$$
R_{n}=\left(R_{s i}-R_{s r}\right)+\left(R_{l i}-R_{l e}\right)
$$

where $R_{s i}$ is the short-wave radiation incident; $R_{s r}$ the short-wave radiation reflected; $R_{l i}$ the long-wave radiation that reaches the canopy, issued by the atmosphere or by the plastic cover; and $R_{l e}$ the long-wave radiation emitted by the canopy and/or soil surface.

\section{Results and Discussion}

\subsection{Solar radiation balance}

Analyzing the curves of Fig. 1a, the global average hourly radiation above the canopies of the covered treatments (PC50 and PC100), from sunrise to sunset, was much lower than that above canopy of the uncovered treatment (WC). In addition, the maximum incident solar radiation reached only about $600 \mathrm{~W} \mathrm{~m}^{-2}$ above canopies of covered treatments while the uncovered treatment reached $975 \mathrm{~W} \mathrm{~m}^{-2}$. For the covered treatments (PC50 and PC100), it is clear that between $6 \mathrm{~h}$ and $10 \mathrm{~h}$ there is no overall difference in incident radiation above the canopies. Between $10 \mathrm{~h}$ and 12:30h, the global solar radiation is slightly larger

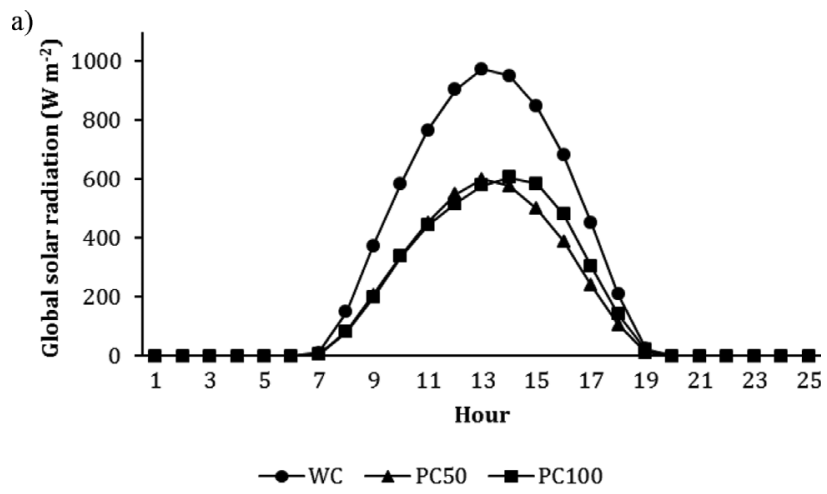

b)

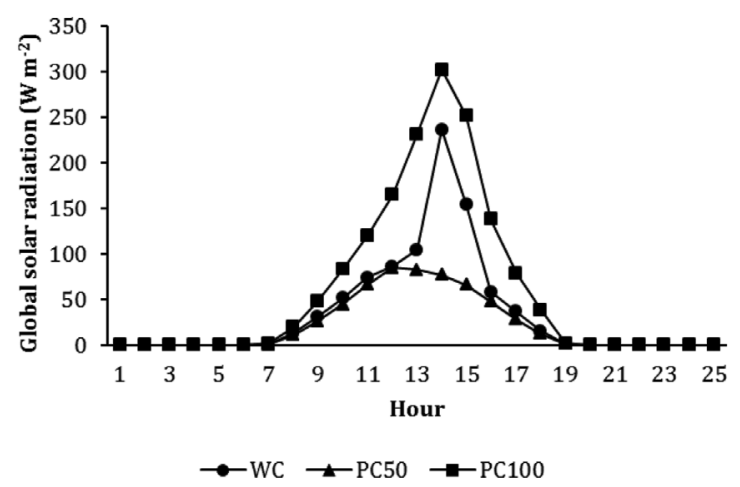

Figure 1 - Behavior of hourly average global solar radiation: (a) above and (b) under the grape festival canopies for treatments: WC, PC50 and $\mathrm{PC} 100$, during phases of maturation and harvest of the grapes. above the PC50 canopy; and from $12: 30 \mathrm{~h}$ to $18 \mathrm{~h}$, there is a turn around, the global radiation becomes greater above the canopy of the PC100 treatment. On the other hand, while the peak global radiation in PC50 treatment occurred at $12 \mathrm{~h}$, in PC100 treatment, this occurred one hour later, at $13 \mathrm{~h}$. The lower incidence of global solar radiation above canopies (PC50 and PC100 treatments) in relation to the uncovered canopy (WC) shows that the plastic cover effectively prevents fair amount of incident solar radiation reaches these canopies.

Table 1 shows that over the covered canopies (PC50 and PC100), the overall average daily solar radiation $\left(R_{s i}\right)$ was much lower than that recorded over the uncovered treatment (WC). That is, while over the uncovered canopy (WC), the average daily incidence global solar radiation was $24.9 \mathrm{MJ} \mathrm{m}^{-2}$ day $^{-1}$, on the covered canopies treatments (PC50 and PC100) it was 14.6 $\mathrm{MJ} \mathrm{m}^{-2} \mathrm{dia}^{-1}$ and 15.4 $\mathrm{MJ} \mathrm{m}^{-2}$ day $^{-1}$, respectively. These data show that in PC50 treatment, the plastic cover missed only $58.6 \%$ of the incident global radiation while in PC100 treatment it missed $61.8 \%$. Therefore, on the average, the plastic cover has prevented about $40 \%$ of the incident global solar radiation to reaches the canopy. This slightly higher percentage of incident global radiation over the canopy (PC100 treatment) is attributed to the fact that the plastic cover has been positioned at greater height in comparison to that of the canopy of PC50 treatment, allowing more solar radiation to penetrate the wing and reach this canopy. According Chavarria and Santos (2009), the plastic cover on vines causes changes in the microclimate and provides favorable conditions for increasing productivity.

However, under the canopy (Fig. 1b), the incidence of solar radiation is quite different from that of above canopies. Both PC50 such as the WC treatments, the hourly average global solar radiation, from sunrise to sunset were lower than that in PC100 treatment. Under the canopies, the global solar radiation peak reached $300 \mathrm{~W} \mathrm{~m}^{-2}$ at PC100, $280 \mathrm{~W} \mathrm{~m}^{-2}$ at $\mathrm{WC}$ and $80 \mathrm{~W} \mathrm{~m}^{-2}$ at PC50 treatments. The curves in Fig. 1b shows that there was a very marked impact of global radiation under the canopy of treatment PC100 compared to PC50 and WC treatments.

Taking as a basis the data in Table 1, it has shown that above canopy, $R_{s i}$ in treatments PC100 and PC50 were $61.8 \%$ and $58.6 \%$ lower than in the WC treatment, respectively. On the contrary, under the canopy, $R_{s i}$ in treatments PC100 and PC50 was 58.5\% higher and $64.5 \%$ lower than in the WC treatment, respectively. The factor that contributed to this significant reduction in global solar radiation under the canopies of WC and PC50 treatments was the leaf area index (LAI) which increased from $3.81 \mathrm{~m}^{-2} \mathrm{~m}^{-2}$ in treatment PC100 to $6.55 \mathrm{~m}^{2} \mathrm{~m}^{-2}$ in WC treatment (Table 1). Therefore, due to this lower LAI of treatment PC100 more global radiation passed through the leaf layer and reached bunches and berries. However, the WC and PC50 treatments, due to its higher LAI, the opposite occurred, fewer 
Table 1 - Behavior of leaf area index (LAI), above and under canopy average daily fluxes of incident $\left(R_{s i}\right)$ and reflected $\left(R_{s r}\right)$ short-wave radiation, net radiation $\left(R_{n}\right)$, long-wave radiation that reaches the canopy $\left(R_{l i}\right)$ and issued the canopy and/or soil surface $\left(R_{l e}\right)$. Values observed in the without coverage (WC), plastic cover positioned at $50 \mathrm{~cm}$ above canopy (PC50) and plastic cover positioned at $100 \mathrm{~cm}$ above canopy (PC100) treatments, during the stages of maturation and harvest.

\begin{tabular}{|c|c|c|c|c|c|c|c|c|c|c|c|}
\hline \multirow[t]{3}{*}{ Treatment } & \multirow[t]{3}{*}{$\operatorname{LAI}\left(\mathrm{m}^{2} \mathrm{~m}^{-2}\right)$} & \multicolumn{10}{|c|}{ Average daily fluxes $\left(\mathrm{MJ} \mathrm{m}^{-2}\right)$} \\
\hline & & \multicolumn{5}{|c|}{ Above the canopy } & \multicolumn{5}{|c|}{ Under the Canopy } \\
\hline & & $R_{s i}$ & $R_{s r}$ & $R_{n}$ & $R_{l i}$ & $R_{l e}$ & $R_{s i}$ & $R_{s r}$ & $R_{n}$ & $R_{l i}$ & $R_{l e}$ \\
\hline WC & 6.55 & 24.9 & 4.9 & 16.3 & 16.0 & 19.4 & 3.1 & 0.8 & 2.4 & 19.6 & 19.5 \\
\hline PC50 & 5.88 & 14.6 & 3.4 & 10.6 & 18.5 & 19.4 & 2.0 & 0.7 & 1.6 & 19.5 & 19.3 \\
\hline PC100 & 3.81 & 15.4 & 2.3 & 12.0 & 18.3 & 19.5 & 5.3 & 0.8 & 4.5 & 19.3 & 19.4 \\
\hline
\end{tabular}

global radiation exceeded these canopies and reached bunches and berries.

Looking to Fig. 2a it can be seen that although the curves of average hourly values of reflected radiation by the canopies present certain symmetry between the morning and afternoon, with the reflection peak occurring at around noon, the radiation reflectivity of each treatment was different. Notably, the WC treatment showed the highest reflection, reaching a peak of $184 \mathrm{~W} \mathrm{~m}^{-2}$, while the PC50 and PC100 treatments reached $130 \mathrm{~W} \mathrm{~m}^{-2}$ and $91 \mathrm{~W} \mathrm{~m}^{-2}$, respectively.

However, analyzing the reflected radiation curves by the ground surface (Fig. 2b), it is observed that the average

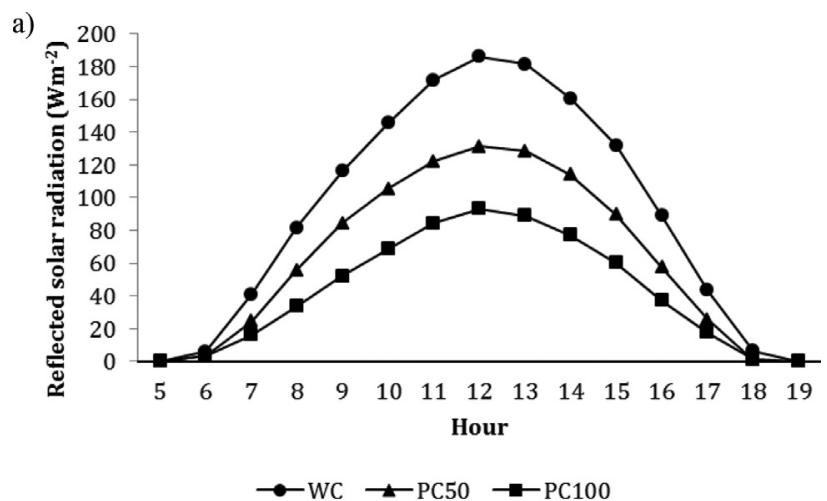

b)

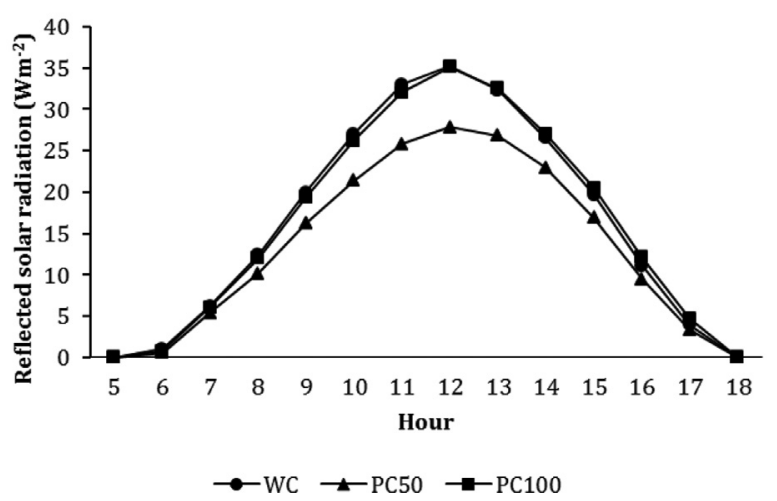

Figure 2 - Average hourly values of reflected solar radiation: (a) above and (b) under the grape festival canopies of treatments: WC, PC50 and PC100 and by their soil surface during phases of maturation and harvesting. hourly reflected radiation in PC50 treatment throughout the day was lower than that observed in WC and PC100 treatments, and that these two canopies showed the same behavior. While the PC50 canopy reached a maximum of $27.7 \mathrm{~W} \mathrm{~m}^{-2}$, the canopies $\mathrm{WC}$ and $\mathrm{PC} 100$ reached maximum values of $35 \mathrm{~W} \mathrm{~m}^{-2}$, but in all canopies, this maximum occurred at $12 \mathrm{~h}$. In terms of daily average albedo of the soil surface, the higher value occurred in PC50 treatment $(23.3 \%)$, followed by WC (19.6\%) and PC100 (14.9\%) treatments. Also, in Table 1, the average daily reflected radiation $\left(R_{s r}\right)$ by canopies of covered treatments (PC50 and PC100) was $69.4 \%$ and $46.9 \%$, respectively of the value recorded in the canopy of uncovered treatment (WC).

In Fig. 3a it turns out that under the canopy of WC treatment, the net radiation during most of the daytime $(7 \mathrm{~h}$ to $16 \mathrm{~h}$ ) was higher than that in the canopies of PC50 and PC100 treatments, and lower at nighttime (17 h to $7 \mathrm{~h})$. In addition, it is noted that, while the peaks of the net radiation in the canopy of WC and PC50 treatments occurred at noon, the peak in the canopy of treatment PC100 occurred at $13 \mathrm{~h}$. Above the canopy of PC100 treatment, the net radiation in the daytime period ( $12 \mathrm{~h}$ to $18 \mathrm{~h}$ ) was higher than that in the canopy of PC50 treatment, but the rest of the day was almost the same. Table 1 shows that the average daily net radiation above canopies of covered treatments $(\mathrm{PC} 50=65.0 \%$ and $\mathrm{PC} 100=73.6 \%)$ was lower than that registered in uncovered treatment (WC), due to presence of the plastic cover. However, the difference between covered treatments is associated with the combined effects leaf layer and height of the cover.

However, it is observed in Fig. $3 b$ that, under the canopy of treatment CP100, the average net radiation $(R n)$ at daytime period ( $7 \mathrm{~h}$ to $18 \mathrm{~h}$ ), was much higher than under the canopies of PC50 and WC treatments. However, Rn under the canopy of WC treatment was greater than that of PC50 treatment, only in the period between $12 \mathrm{~h}$ and $15 \mathrm{~h}$. For the rest of the day it was always very near. On the other hand, also it appears that in percentage terms, the $R n$ under the canopy of WC and PC50 treatments was lower (46.7\% and $64.4 \%$, respectively) of that under the canopy of treatment (PC100). Therefore, as the type of plastic used in both PC50 and PC100 treatments was the same, this reinforces the statement that the lower LAI in the canopy of PC100 

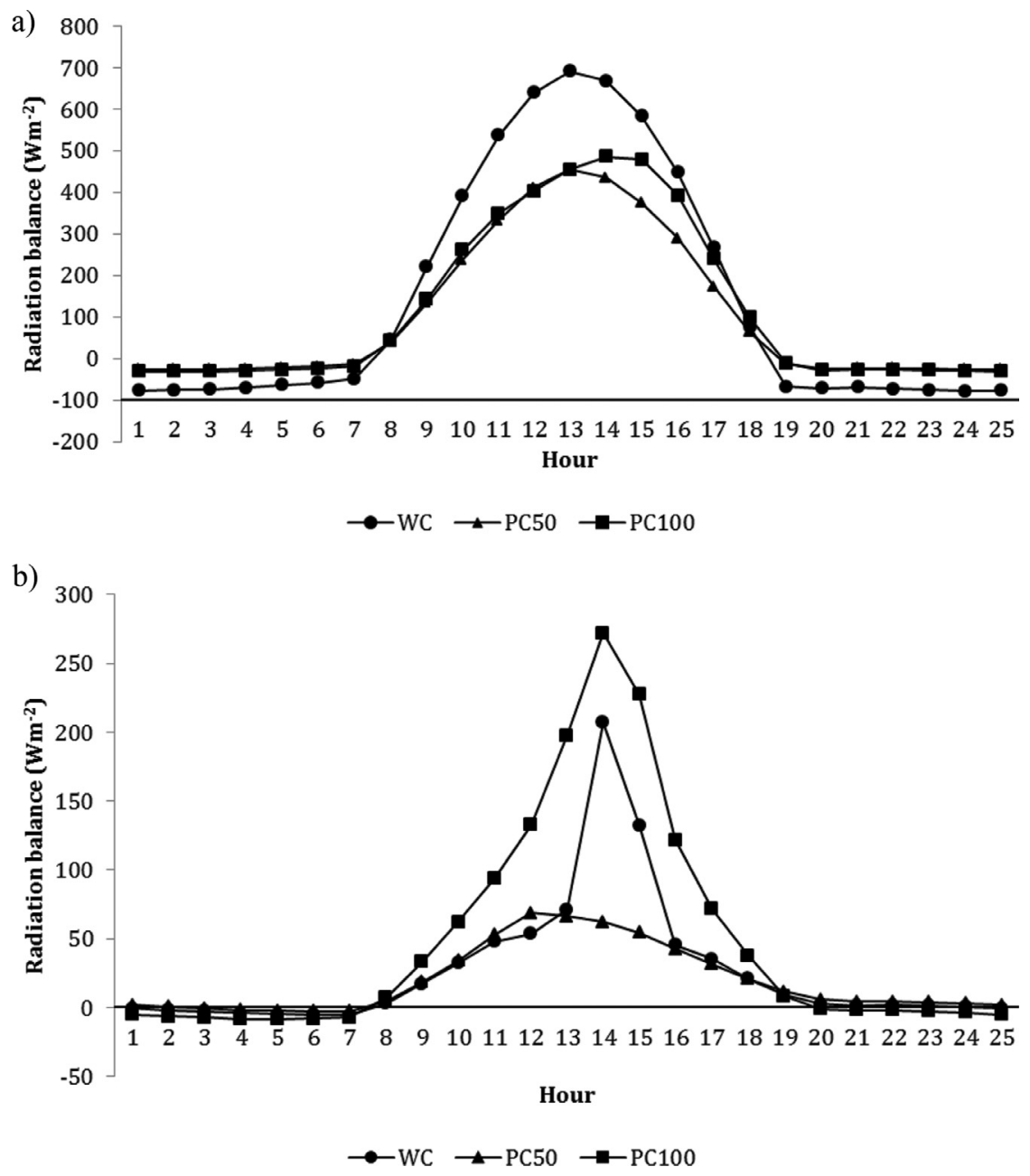

Figure 3 - Behavior of the average hourly radiation balance: (a) above and (b) under the grape festival canopies for treatments: WC, PC50 and PC100, during phases of maturation and harvest of the grapes.

treatment contributed to a greater passage of global radiation by this canopy, which in turn generated a greater availability of under the canopy. On the other hand, these results also show that under the canopies of the treatments in which the LAI was higher (WC and PC50) due to lower incidence of global radiation, there was a significant reduction of $R n$. This may be decisive to the physiological processes of the plants and hence to reduced productivity in the WC and PC50 treatments.

Regarding the long-wave radiation emitted by the plastic cover into the canopy $\left(R_{l e}\right)$, there was practically no difference between the covered treatments (PC50 and PC100) (Table 1). However, above the canopy of the uncovered treatment (WC), the long-wave radiation from the atmosphere $\left(R_{l i}\right)$ was lower than that observed above the canopy of the covered treatments. On average, the emission of radiation by the cover in the PC50 and PC100 treatments, contributed to increase by $13 \%$ to long-wave radiation above the canopies of these treatments.

\subsection{Behavior of air temperature, relative humidity and wind speed}

Analyzing the Fig. 4a, it turns out that above the canopies with plastic cover, while the maximum values of hourly average temperature occur at $13 \mathrm{~h}$, above the canopy without coverage (natural conditions), the maximum temperature occurs at $15 \mathrm{~h}$. On the other hand, while in the period from $7 \mathrm{~h}$ to $16 \mathrm{~h}$ the hourly average temperature above the canopy PC50 treatment was higher than that above the canopies of treatments PC100 and WC, in other times of the day the hourly average temperature above the canopy PC50 treatment was lower than that of the other two treatments. Between 0 and $7 \mathrm{~h}$ and between 16 to $24 \mathrm{~h}$, the hourly average temperature above the WC canopy was higher than that above the canopies of covered treatments. This indicates that, unlike the daytime temperature above the canopy without covering from the late afternoon throughout nighttime period was higher than that above the canopies with plastic sheeting. This occurs because the plastic cover cools 


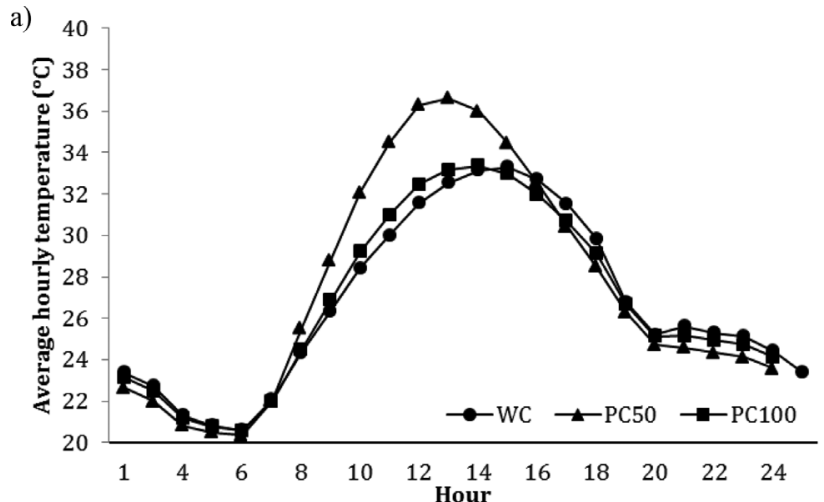

b)

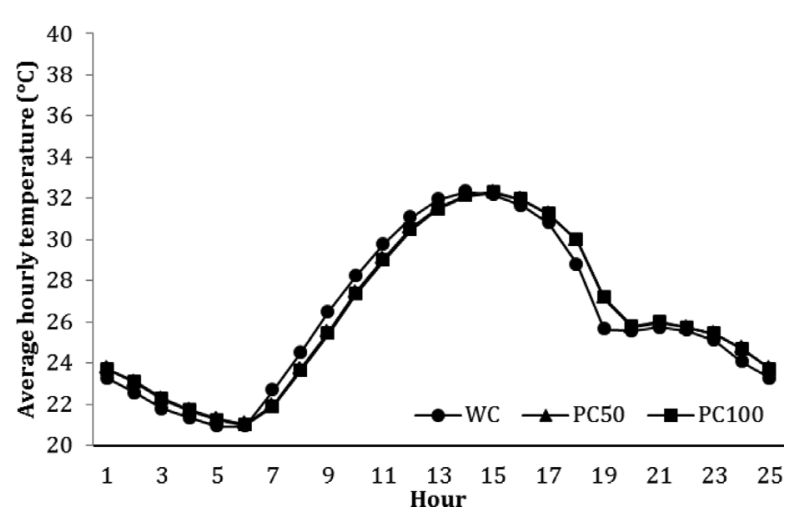

Figure 4 - Average hourly temperature: (a) above and (b) under the grape festival canopies for treatments: WC, PC50 and PC100, during phases of maturation and harvest of the grapes.

faster and brings the air under it to cool more than the air over the uncovered canopy.

However, analyzing the curves in Fig. 4b, it is observed that the under hourly average air temperature at the height of the bunches in all canopies, has practically no difference and shows the same daily behavior, start the day with a gentle drop to achieve a minimum $21{ }^{\circ} \mathrm{C}$ at $5 \mathrm{~h}$. Thereafter increases to a maximum of $32.8^{\circ} \mathrm{C}$ around $13 \mathrm{~h}$ and then remains more or less constant until $15 \mathrm{~h}$, reducing progressively to reach $24{ }^{\circ} \mathrm{C}$ at $19 \mathrm{~h}$. After $19 \mathrm{~h}$, for some reason, the hourly average air temperature at the height of bunches experienced a slight increase until it reaches $25^{\circ} \mathrm{C}$ at $22 \mathrm{~h}$. These data show that the plastic covering did not influence the hourly average air temperature under the canopies.

In Fig. 5 ( $a$ and $b$ ), it is shown the trend of the maximum daily temperature during the experimental period. It is observed that in the days when the maximum air temperature of the PC50 canopy does not exceed $37^{\circ} \mathrm{C}$, the air temperature difference between this canopy and the WC canopy is about $3{ }^{\circ} \mathrm{C}$, but when the air temperature of the PC50 canopy is higher than $37^{\circ} \mathrm{C}$, the difference can reach around $9{ }^{\circ} \mathrm{C}$. On the other hand, even on hot days, the air temperature difference between treatments PC100 and WC on average does not exceed $2^{\circ} \mathrm{C}$. This shows that in relation to the plastic cover positioned $50 \mathrm{~cm}$ above the canopy,
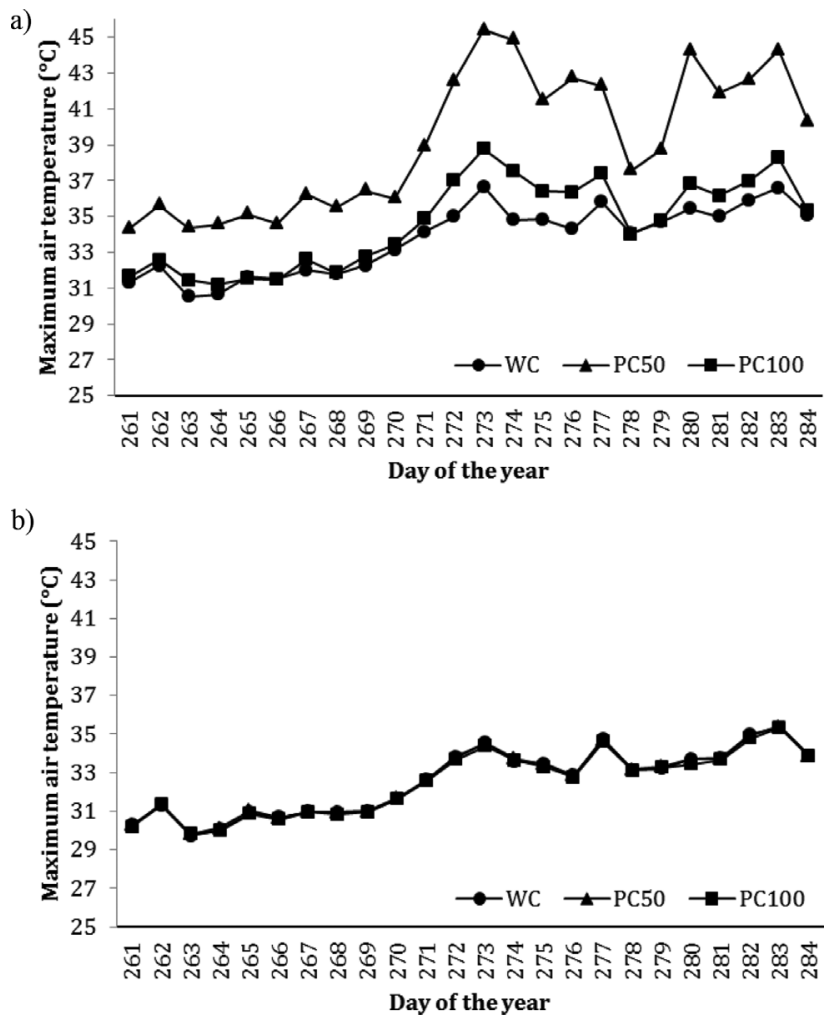

Figure 5 - Evolution of the daily maximum air temperature: (a) above and (b) under the grape festival canopies for treatments: WC, PC50 and PC100, during phases of maturation and harvest of the grapes.

plastic sheeting positioned at $100 \mathrm{~cm}$ does not generate heat so intense above canopy.

Similar results were obtained in vineyard $18 \%$ shaded by using polythene sheeting where the maximum temperature in the vineyard did not differ, in general, the amounts recorded at the weather station (Conception and Marin, 2009). Therefore, the height of the plastic cover above the canopy is a very important factor for the establishment of the vineyard microclimate. Therefore, it should be taken into account in planning the structure of the greenhouse system.

Heating the plastic cover was also observed by Cardoso et al. (2008) for the temperate conditions in Rio Grande do Sul, but the difference was much smaller, average increase of $3.4^{\circ} \mathrm{C}$ in maximum temperature close to the crop, going from $28.4^{\circ} \mathrm{C}$ above covering to about $31.8^{\circ} \mathrm{C}$ between cover and the canopy. Chavarria et al. (2007) observed an increase of $1{ }^{\circ} \mathrm{C}$ in the average temperature of plastic covered vines compared to vines exposed to open air, and said that this increment is due to the maximum temperatures of $31.8^{\circ} \mathrm{C}$ and $28.0^{\circ} \mathrm{C}$ at the covered and uncovered areas, respectively.

In the case of air relative humidity, due to non-availability of psychrometers, the measurements were made just above canopies. Therefore, analyzing the moisture curves of the air hourly average of the interior of the vine- 


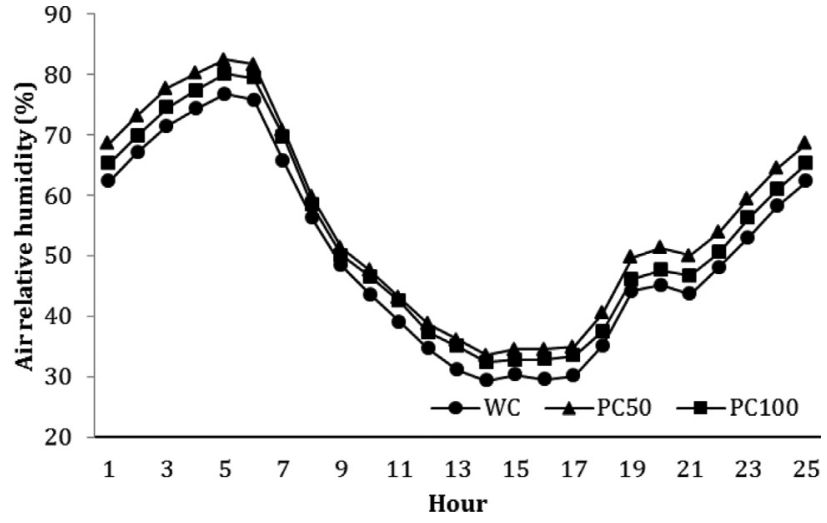

Figure 6 - Behavior of average hourly air relative humidity at the height of the grape clusters above the grape festival canopies for treatments: WC, PC50 and PC100, during phases of maturation and harvest of the grapes.

yards, at the branches height (Fig. 6), it is observed that the moisture content in covered treatments (PC50 and PC100) was for every moment of day higher than that observed in the without cover treatment (WC), i.e. in the WC canopy, the average hourly relative humidity throughout the day has always remained lower, followed by the PC100 and PC50 canopies, which showed the highest moisture contents. The daily evolution of moisture shows that higher humidity values occurred in all treatments around 6 am, reaching the canopy PC50 an average of $82.5 \%$ in the canopy PC100 $79.2 \%$ and $76.8 \%$ in the canopy WC.

The relative humidity in all canopies from midnight gradually increases until it reaches the maximum value at $6 \mathrm{~h}$, while the lowest values occurred between $13 \mathrm{~h}$ and $16 \mathrm{~h}$, reaching the WC canopy $29.5 \%$; canopy PC100 and PC50 32.9\% 34.5\% canopy, and from $17 \mathrm{~h}$ to $24 \mathrm{~h}$ increases again. However, there is a difference between the average PC50 and PC100 treatment $2.8 \%$, and for the treatment WC of $5.8 \%$. These data show that the plastic cover contributes to the retention of water vapor inside the vineyard. However, Chavarria et al. (2007) in a survey conducted in vineyard Moscato Giallo, in Flores da Cunha - RS, found no difference relative humidity of air between covered and discovery areas.

Making up finally an analysis of the behavior of average hourly wind speed on canopies (Fig. 7a), it is observed that on the covered canopies (PC50 and PC100) the average hourly wind speed was extremely small compared with that observed above the uncovered canopy (WC), and above the PC50 canopy it was literally almost nil. In warmer moments of the day, the average hourly wind speed above WC treatment was even higher than under the covered canopy. The vineyards coverage makes the air even more heated above the covered canopies, and the effect is greater due to the reduction of the height of the roof.

In Flores da Cunha - RS vineyards conducted in system, "Y" was observed that in uncovered vineyards, average wind speed of $0.91 \mathrm{~m} \mathrm{~s}^{-1}$ while below the plastic cover

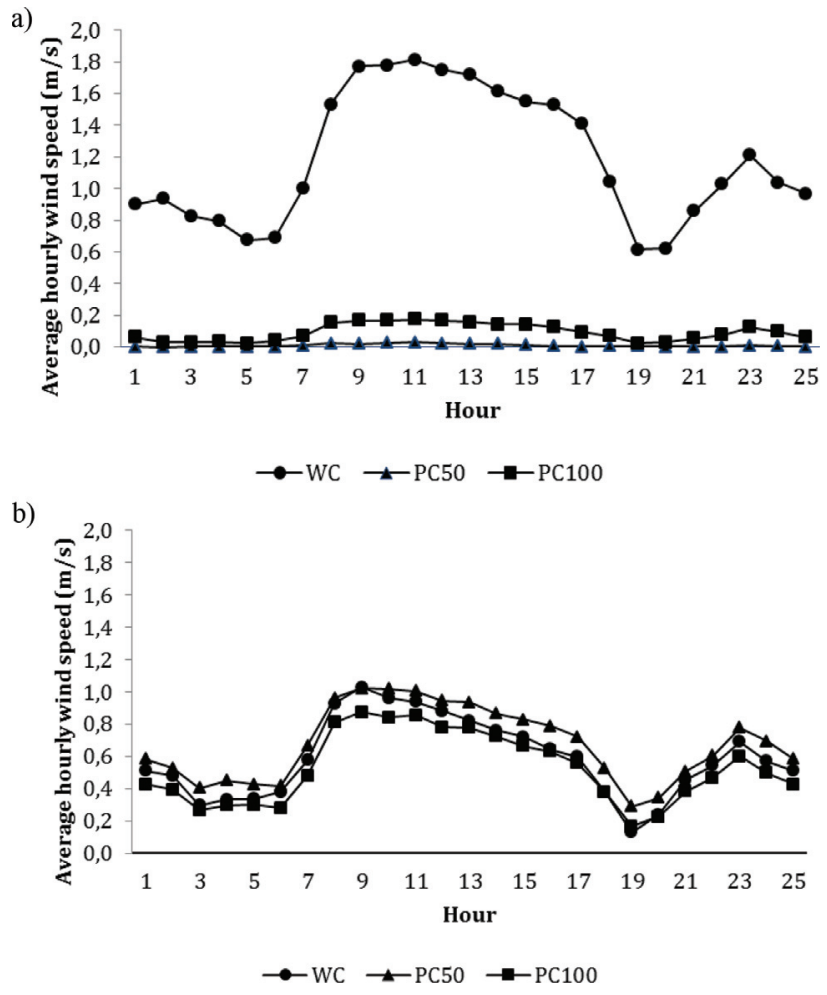

Figure 7 - Behavior of average hourly wind speed at the height of the grape clusters: (a) above and (b) under the grape festival canopies for treatments: WC, PC50 and PC100, during phases of maturation and harvest of the grapes.

the average wind speed was smaller than $0.1 \mathrm{~m} \mathrm{~s}^{-1}$. This shows that the plastic cover in fact stands as a physical barrier to the movement of air, significantly reducing the wind speed over the open canopy (Cardoso et al., 2008). However, analyzing the evolution of the average hourly wind speed beneath canopies at the height of the clusters (Fig. 7b), it is clear also that while the movement of air under the canopy of the uncovered treatment (WC) was more pronounced, under the treatments with plastic sheeting there was also air movement. However, the maximum average hourly wind speed in all canopies did not exceed $1.1 \mathrm{~m} \mathrm{~s}^{-1}$. Therefore, unlike without coverage treatment (WC), the covered treatments (PC50 and PC100), the plastic cover to prevent the rising convective air movement on these canopies, as already mentioned, also helped to reduce the displacement of air inside the vineyards.

Analyzing the productivity of the treatments studied (Table 2); it is observed that while the average physical productivity of treatment PC100 was $30.9 \mathrm{t} \mathrm{ha}^{-1}$, treatments (WC and PC50) were $18.9 \mathrm{t} \mathrm{ha}^{-1}$ and $17.8 \mathrm{t} \mathrm{ha}^{-1}$, respectively. Therefore, the physical productivity of PC100 treatment exceeded by $38.8 \%$ that of the WC treatment and $42.4 \%$ of PC50 treatment. So that, the productivity of PC100 treatment was statistically superior to those of WC and PC50 treatments, which were not statistically different from each other. In relation to business productivity, the to- 
Table 2 - Leaf area index (LAI) and physical and commercial Productivity Grape variety Festival for treatments: without plastic cover (WC), plastic cover positioned at $50 \mathrm{~cm}$ above the canopy (PC50) and at $100 \mathrm{~cm}$ above the canopy (PC100)

\begin{tabular}{|c|c|c|c|c|}
\hline \multirow[t]{2}{*}{ Treatment } & \multirow{2}{*}{$\begin{array}{c}\text { LAI } \\
\left(\mathrm{m}^{2} \mathrm{~m}^{-2}\right)\end{array}$} & \multirow{2}{*}{$\begin{array}{l}\text { Physical productivity } \\
\qquad\left(\mathrm{t} \mathrm{ha}^{-1}\right)\end{array}$} & \multicolumn{2}{|c|}{ Commercial Productivity $\left(\mathrm{t} \mathrm{ha}^{-1}\right)$} \\
\hline & & & Scenario $1(*)$ & Scenario $2(* *)$ \\
\hline WC & 6.55 & 18.9 & 15.6 & 16.7 \\
\hline PC50 & 5.88 & 17.8 & 15.4 & 16.3 \\
\hline PC100 & 3.81 & 30.9 & 26.9 & 28.0 \\
\hline
\end{tabular}

*Total elimination of clusters with severe defects (cracked and berry stems with disease);

**Partial Elimination of clusters with severe defects, not observing the Normative Instructions No. 01 - MAPA of February 1, 2002 (Brasil, 2002).

tal elimination of grapes with severe defect (scenario 1), due to the significant amount of discarded bulk berries in WC and PC50 treatments, the difference was even greater $42.0 \%$ and $42.7 \%$, respectively. The loss of business productivity in scenario 1 conditions decreased by $17.5 \%$ the physical productivity of WC treatment, $13.5 \%$ of PC50 treatment and $12.9 \%$ of $\mathrm{PC} 100$ treatment. This makes it possible to infer that the plastic cover positioned at $100 \mathrm{~cm}$ above canopy influenced positively the physical productivity of vineyard, increasing its production, compared to that of the uncovered (WC) and covered PC50 treatments.

Marketable yield for scenarios 1 and 2 (Table 2) is the most important focus of grape evaluation, according to the Normative Instructions of the Ministério da Agricultura, Pecuária e Abastecimento (MAPA) (Brasil, 2002). These results clearly demonstrate that the height of the plastic cover over grapevines canopy generates different climatic conditions and consequently impacts on the physical and commercial yields. Detoni and Fornari (2007) obtained for plastic covered vineyards production three and a half higher $\left(1,769 \mathrm{~g} \mathrm{plant}^{-1}\right)$ than that for in plants without cover (492 g plant $^{-1}$ ).

\section{Conclusions}

The results of research on the effects of the plastic cover to the microclimate of vineyards in the San Francisco River Valley region showed that the low-density polyethylene (LDPE), thickness of $160 \mu \mathrm{m}$, traditionally used to cover vineyards in the region provides the following changes in the microclimate of the vineyards:

a) It prevents about $40 \%$ of global solar radiation reaches the canopy;

b) The plastic cover was able to promote the retention of air humidity inside the vineyard, by limiting the evapotranspiration flux emerging from the vegetated surface in direction to the atmospheric boundary layer;

c) Depending on the height at which is positioned a plastic cover creates intense heating of the air layer over the canopy during daytime;

d) In the spring, a time of higher air temperatures, the plastic cover positioned at $50 \mathrm{~cm}$ above the canopy, a practice adopted by winemakers in the region, generates sharp warming, prevents the movement of air over the canopy and reduces productivity. By contrast, when positioned at $100 \mathrm{~cm}$ above the canopy, the plastic cover provides heating the air and a little more air circulation over the canopy, and provide a $40 \%$ increase in vineyard productivity.

e) Therefore, for the climatic conditions of the lowermiddle San Francisco River, the plastic sheeting positioned at $100 \mathrm{~cm}$ above the canopy is the most suitable alternative for the region.

\section{References}

BRASIL: Ministério da Agricultura, Pecuária e Abastecimento MAPA. Instrução Normativa $n^{\circ} 1$, de $1^{\circ}$ de fevereiro de 2002. Regulamento técnico de identidade e de qualidade para a classificação da uva fina de mesa. Diário Oficial da República Federativa do Brasil, Brasília, 4 de fevereiro de 2002, Seção 1., 7p.

CARDOSO, L.S.; BERGAMASCHI, H.; COMIRAN, F.; CHAVARRIA, G.; MARODIN, G. A.B.; DALMAGO, G.A.; SANTOS, H.P.; MANDELI, F. Alterações micrometeorológicas em vinhedos pelo uso de coberturas de plástico. Pesquisa Agropecuária Brasileira, v.43, n.4, p.441-447, 2008.

CHAVARRIA, G.; CARDOSO, L.S.; BERGAMASCHI, H.; SANTOS, H.P.; MANDELLI F.; MARODIN, G.A.B. Microclima de vinhedos sob cultivo protegido. Ciência Rural, v. 39, n. 7, p. 2029-2034. 2009.

CHAVARRIA, G.; SANTOS, H.P. dos; SÔNEGO, O.R.; MARODIN, G.A.B.; BERGAMASCHI, H.; CARDOSO, L.S. Incidência de doenças e necessidade de controle em cultivo protegido de videira. Revista Brasileira de Fruticultura, v. 29, n. 3, p. 477-482, 2007.

CHAVARRIA, G.; SANTOS, H.P. Manejo de videiras sob cultivo protegido. Ciência Rural, v. 39, n. 6, p.1917-1924, 2009.

CHORTI, E.; GUIDONI, S.; FERRANDINO, A.; NOVELLO, V. Effect of different cluster sunlight exposure levels on ripening and anthocyanin accumulation in nebbiolo grapes. American Journal of Enology and Viticulture, v. 61, n. 3, p. 23-30, 2010.

COLOMBO, L.A.; ASSIS, A.M.; SATO, A.J.; TESSMANN, D.J.; GENTA, W.; ROBERTO, S.R. Produção fora de época da videira 'BRS Clara' sob cultivo protegido. Ciência Rural, v. 41, n. 2, p. 212-218, 2011.

CONCEIÇÃO, M.A.F.; MARIN, F.R. Condições microclimáticas em um parreiral irrigado coberto com tela plástica. Revista Brasileira de Fruticultura, v. 31, n. 2, p. 423-431, 2009. 
DETONI, A.M.; CLEMENTE, E.; FORNARI, C. Produtividade e qualidade da uva 'cabernet sauvignon' produzida sob cobertura de plástico em cultivo orgânico. Revista Brasileira de Fruticultura, v. 29, n. 3, p. 530-534, 2007.

FAO - Organización de las Naciones Unidas para la Agricultura y la Alimentación. El cultivo protegido en clima mediterrâneo. FAO, Roma, 2002, 27pg. (Manual preparado por el Grupo de Cultivos Hortícolas Dirección de Producción y Protección Vegetal). ftp.fao.org/docrep/fao/005/s8630S/ s8630S00.pdf.

GAMBINO, C.; DIMAURO B.; DI LORENZO, R. Comportamento vegeto-produttivo ed ecofisiológico di viti allevate fuori suolo in serra. Frutticoltura, v. 200. n. 1, p. 20-24, 2008.

GENTA, W.; TESSMANN, D.J.; ROBERTO, S.R.; VIDA, J.B.; COLOMBO, L.A.; SCAPIN, C.R.; RICCE, W.S.; CLOVIS, L.R. Manejo de míldio no cultivo protegido de videira de mesa 'BRS Clara'. Pesquisa Agropecuária Brasileira, v.45, n. 12, 2010.

LAMAS JUNIOR, G.L.C. Ecofisiologia e fitotecnia do cultivo protegido de videira cv. MOSCATA GIALLO (Vitis vinera L). Porto Alegre - RS. Universidade Federal do Rio Grande Sul. 136p. 2008. Tese de doutorado.

LEITÃO, M.M.V.B.R. Balanço de radiação em três ecossistemas da floresta amazônica: capina, campinarana e mata densa. Instituto Nacional de Pesquisas Espaciais. 1994. São José dos Campos. SP. (Tese de doutoramento, 135 p).

LULU, J.; CASTRO, J.V.; PEDRO JÚNIOR, M.J. Efeito do microclima na qualidade da uva de mesa 'romana' (A 1105) cultivada sob cobertura Plástica. Revista Brasileira de Fruticultura, v. 27, n. 3, p. 422-425, 2005.
PALMA, L. DE; NOVELlO, V., TARRICONE, L. Changes of solar radiation and air $\mathrm{CO} 2$ concentration: effects on ecophysiological activity, vine growth and production in table grape grown under protected conditions. In: XI Meeting Study Group for Vine Training Systems. Marsala. Universitàde Gli Studi di Palermo, v. 2. p. 711-717, 1999.

PEDRO JÚNIOR, J.M. Microclima de vinhedos cultivados sob cobertura plástica e a céu aberto. Revista Brasileira de Agrometeorologia, v.14, p.106-115, 2006.

RANA, G.; KATERIJI, N.; INTRONA, M.; HAMMAMI, A. Microclimate and plant water relationship of the "overhead" table grape vineyard managed with three different covering techniques. Scientia Horticulturae, v. 102, p. 105-120, 2004.

SANTOS, A.O.; PEDRO JÚNIOR, J.M.; FERREIRA, M.A.; HERNANDEZ, J.L. Ecophysiology and yield performance of grape Cabernet sauvignon cultivated under different exposures. Acta Scientiarum. Agronomy, v. 26, n. 3, p. $263-$ 271, 2004.

SILVA, P.C.L.; RAMOS LEITÃO, M.M.V.B.; AZEVEDO, P.V. Influência da Cobertura Plástica Sobre a Temperatura em Parreirais no Vale do Submédio São Francisco. Revista Brasileira de Geografia Física, v.1, p.045-056, 2011.

VIEIRA, H.J.; SILVA, A.L.; ARCRI, S.G.; BRUNA, E.D.; BACK, A.J.; PANDOLFO, C. Rachaduras da uva Goethe em condições de alta umidade do ambiente. In: XII Congresso Brasileiro de Viticultura e Enologia - Anais. Bento Gonçalves, de 22 a 24 de setembro de 2008, 92 p.

This is an Open Access article distributed under the terms of the Creative Commons Attribution Non-Commercial License which permits unrestricted non-commercial use, distribution, and reproduction in any medium provided the original work is properly cited. 